Pesq. Vet. Bras. 35(1):55-61, janeiro 2015

DOI: $10.1590 / \mathrm{S} 0100-736 \mathrm{X} 2015000100012$

\title{
Red eyes in the necropsy floor: twenty cases of hyphema in dogs and cats ${ }^{1}$
}

\author{
Tessie Beck Martins ${ }^{2}$ and Claudio S.L. Barros ${ }^{2 *}$
}

\begin{abstract}
Martins T.B. \& Barros C.S.L. 2015. Red eyes in the necropsy floor: twenty cases of hyphema in dogs and cats. Pesquisa Veterinária Brasileira 35(1):55-61. Programa de Pós-Graduação em Medicina Veterinária, Universidade Federal de Santa Maria, Camobi, Santa Maria, RS 97105-900, Brazil. E-mail: claudioslbarros@uol.com.br

Hyphema (hemorrhage within the anterior chamber of the eye) can be caused by several mechanisms and can easily be detected in routine ophthalmic or necroscopic examination as discolored red eye(s). The purpose of this study is to report the cause of hyphema diagnosed as a postmortem finding in dogs and cats. Twenty cases, 14 dogs and six cats of several ages and breeds and of both sexes were included in the study. Hyphema presented as a unilateral (14 cases out of 20) or bilateral (6/20) disorder in dogs and cats and extension of hemorrhage varied from minimal to diffuse. Hyphema was secondary to systemic disease $(15 / 20)$ or occurred as a primary ocular lesion $(5 / 20)$ in four dogs and one cat. Primary hyphema was always unilateral. In four of these cases, the cause of hyphema was trauma and remaining case was caused by phacoclastic uveitis in a dog with bilateral hypermature cataract. Various causes of bleeding disorders were found related to secondary hyphema: in decreasing order of frequency, they included vasculitis $(8 / 15)$, systemic hypertension $(5 / 15)$, and acquired coagulopathies (2/15). Vasculitis due to feline infectious peritonitis accounted for half of the cases $(n=3)$ of systemic hyphema in cats. The various pathological aspects and pathogenesis of hyphema in dogs and cats are described and discussed.
\end{abstract}

INDEX TERMS: Ophthalmic pathology, intraocular hemorrhage, vasculitis, systemic hypertension.

RESUMO.- [Olhos vermelhos na sala de necropsia: vinte casos de hifema em cães e gatos.] Hifema, hemorragia na câmara anterior do olho, pode ser causada por vários mecanismos e pode facilmente ser detectada no exame oftálmico de rotina ou na necropsia como olho(s) vermelhos(s). 0 objetivo deste trabalho é relatar as causas de hifema diagnosticado como um achado postmortem em cães e gatos. Vinte casos, 14 cães e seis gatos de várias idades e raças, e de ambos os sexos foram incluídos no estudo. 0 hifema em cães e gatos teve uma apresentação unilateral (14 casos dos 20) ou bilateral (6/20), e a extensão da hemorragia variou de mínima a difusa. 0 hifema era secundário à doença sistêmica (15/20) ou ocorreu como lesão ocular

\footnotetext{
${ }^{1}$ Received on January 5, 2014.

Accepted for publication on January 19, 2015.

Part of Doctoral Degree of the first author.

${ }^{2}$ Programa de Pós-Graduação em Medicina Veterinária, área de concentração em Patologia Veterinária, Centro de Ciências Rurais (CCR), Universidade Federal de Santa Maria (UFSM), Av. Roraima 1000, Camobi, Santa Maria, RS 97105-900, Brazil. *Corresponding author: claudioslbarros@ uol.com.br
}

primária em cinco dos 20 casos (quatro cães e um gato). O hifema primário foi sempre unilateral; em quatro desses casos, a causa foi traumatismo e o caso restante foi causado por uveíte facoclástica em um cão com catarata hipermadura bilateral. Várias causas de distúrbios hemorrágicos foram encontradas em relação ao hifema secundário: em ordem decrescente de frequência foram: vasculite $(8 / 15)$, hipertensão sistêmica $(5 / 15)$ e coagulopatias adquiridas $(2 / 15)$. Os vários aspectos patológicos e a patogênese do hifema são descritos e discutidos.

TERMOS DE INDEXAÇÃO: Patologia oftálmica, hemorragia intraocular, vasculite, hipertensão sistêmica.

\section{INTRODUCTION}

Hyphema, or hemophthalmos (Dubielzig et al. 2010), is defined as hemorrhage within the anterior chamber of the eye (Miller 2008). There are numerous potential intraocular causes for hyphema, such as blunt or penetrating trauma, inflammation, retinal detachment (Dubielzig et al. 2010), primary or metastatic neoplasia, iatrogenic procedures 
(Willis 2003), congenital anomalies, and chronic glaucoma (Powell 2002). Hyphema may also result from systemic diseases, including widespread inflammation (Powell 2002) and vasculitis associated with infectious diseases (Sorrell et al. 2008), severe acute anemia (Komáromy et al. 1999), systemic hypertension, and disorders of hemostasis (Dubielzig et al. 2010), like coagulopathies and hyperviscosity syndromes (Willis 2003). Indeed, many of the mechanisms that cause intraocular hemorrhage may also result in hemorrhage in other parts of the body, and that makes hyphema a "red flag" for life threatening systemic hemorrhagic disease as well as for sight-threatening ocular illnesses (Komáromy et al. 1999).

In a small animal routine necropsy, seldom there is a detailed dissection of the eyes unless the history, clinical signs, or obvious necropsy changes warrant detailed attention (Moreland 2009), but hyphema is usually easily detectable (Bjerkås et al. 2009), and its observation can be the first clue to the cause of death when clinical history is poor or not available. The purpose of this study is to report the cause of hyphema diagnosed as a postmortem finding in twenty dogs and cats submitted to necropsy.

\section{MATERIALS AND METHODS}

Records from necropsies performed between 2000 and 2013 by the Veterinary Pathology Laboratory, at the Federal University of Santa Maria (LPV-UFSM), were reviewed. Reports from dogs and cats in which hyphema was diagnosed at the time of the necropsy were included in this study. Data collected included signalment, history, cause of death or reason for euthanasia, general and ocular clinicopathologic abnormalities, and final diagnoses. The authors attended the necropsy of part of these animals, especially during the years of 2011 and 2012.

In all cases, eyes were evaluated grossly during necropsy, before removal from their orbits, under natural light and/ or fluorescent-lit room. In some cases, the head of the animal was placed facing the sun in order to enhance the red color in the anterior chamber. No ophthalmologic test was performed. After postmortem enucleation, eyebulbs were cleaned from extra-ocular tissues and placed in formalin or Davidson's fixative, cleaved within 48 hours and processed routinely for confection of hematoxylin-and-eosin slides, which were evaluated through optic microscopy.

Hyphema was classified according to distribution, as unilateral [right eye (oculus dexter; OD) or left eye (oculus sinister; OS)] or bilateral [both eyes (oculus uterque; OU)]; according to nature of hemorrhage, as systemic or ocular; and according to mechanism of bleeding. Hemorrhage was considered of systemic nature when the ocular lesions were part of or secondary to a generalized disease [e.g. cardiac failure, feline infectious peritonitis (FIP)], whereas the term ocular nature was used when bleeding could be explained by lesions targeting eye structures specifically (such as corneal trauma or cataract). Classification according to mechanism of hemorrhage was based on a previous study about causes of hyphema in animals (Komáromy et al. 1999), where lesions were divided by categories considering its etiopathogenesis, as follows: trauma; thrombocytopenia; thrombocytopathy; coagulopathy; vasculitis and uveitis; noninflammatory vascular disorders; hyperviscosity syndrome; systemic hypertension; neovascularization of uveal and retinal tissues; congenital anomalies; and anemia.

\section{RESULTS}

Twenty cases, fourteen dogs and six cats, were included in this study. Ages varied between seven months and sixteen years. Twelve animals, including all cats, were mixed breed, and seven were purebred; in one protocol, information about breed was not available. Males and females appeared in the same proportion, although there were more male cats and female dogs.

Hyphema presented as collection of blood within, but not always limited to, the anterior chamber of one $(14 / 20)$ or two $(6 / 20)$ eyes. Extension of hemorrhage varied from minimal to diffuse, but such feature could not be systematically evaluated because few protocols contained that information. Usually, gross description was limited to "blood in anterior chamber (hyphema)". In most cases (15/20), hyphema was secondary to systemic disease whilst primary ocular lesions were less common $(5 / 20)$.

Primary ocular disease was cause for hyphema in one cat and four dogs, and these lesions were always unilateral. In the cat and three of the dogs (4/5), hemorrhage was due to head trauma, that was followed by ocular proptosis in one dog. In two dogs, hemorrhage was secondary to perforating corneal injuries (caused by car accident in one dog and presumed animal fight in another dog). Ocular lesions were characterized by multiple small foci of hemorrhage in the anterior and/or posterior uvea, presumably due to vascular rupture. A thin pre-iridal fibrovascular membrane (PIFM) was present in one dog, and traumatic uveitis, in another. Finally, one case of primary ocular lesion causing hyphema was precipitated by phacoclastic uveitis in a dog with bilateral hypermature cataract (Fig.1); a ruptured lens was surrounded by pyogranulomatous inflammation, and blood and fibrin filled the anterior and posterior chamber. Iridal and ciliary blood vessels were markedly ingurgitated, and lymphocytes and plasma cells were present in the iris. This dog died because of mycotic gastritis associated with hyphae invasion of gastric mucosal blood vessels.

Various causes of bleeding disorders were found related to systemic hyphema: in decreasing order of occurrence, they included vasculitis $(8 / 15)$, systemic hypertension $(5 / 15)$, and acquired coagulopathies $(2 / 15)$.

Vasculitis due to feline infectious peritonitis (FIP) was the main cause of hyphema with systemic origin in cats, and accounted for half of feline cases in this study. Two animals presented bilateral hyphema. A third cat, that had a blood clot for hyphema (Fig.2), had also hemorrhagic uveitis in the contralateral eye, but there was no free blood in the anterior chamber. Pyogranulomatous anterior uveitis was present in all animals, and chorioretinits, in one. Vascular necrosis was not obvious in any of the eyes, but it could be seen in other organs. In one animal, aside from the vascular changes, PIFM was present in both eyes.

Vasculitis was secondary to septicemia/endotoxemia in three cases - two dogs with pyometra (Fig.3-4) and one cat with septic peritonitis secondary to perforated gastric ulcer (Fig.5). Presentation was bilateral in the dogs and unilateral in the cat. Lesions in these cases were composed of discreet neutrophilic vasculitis, thrombi and leucocytos- 

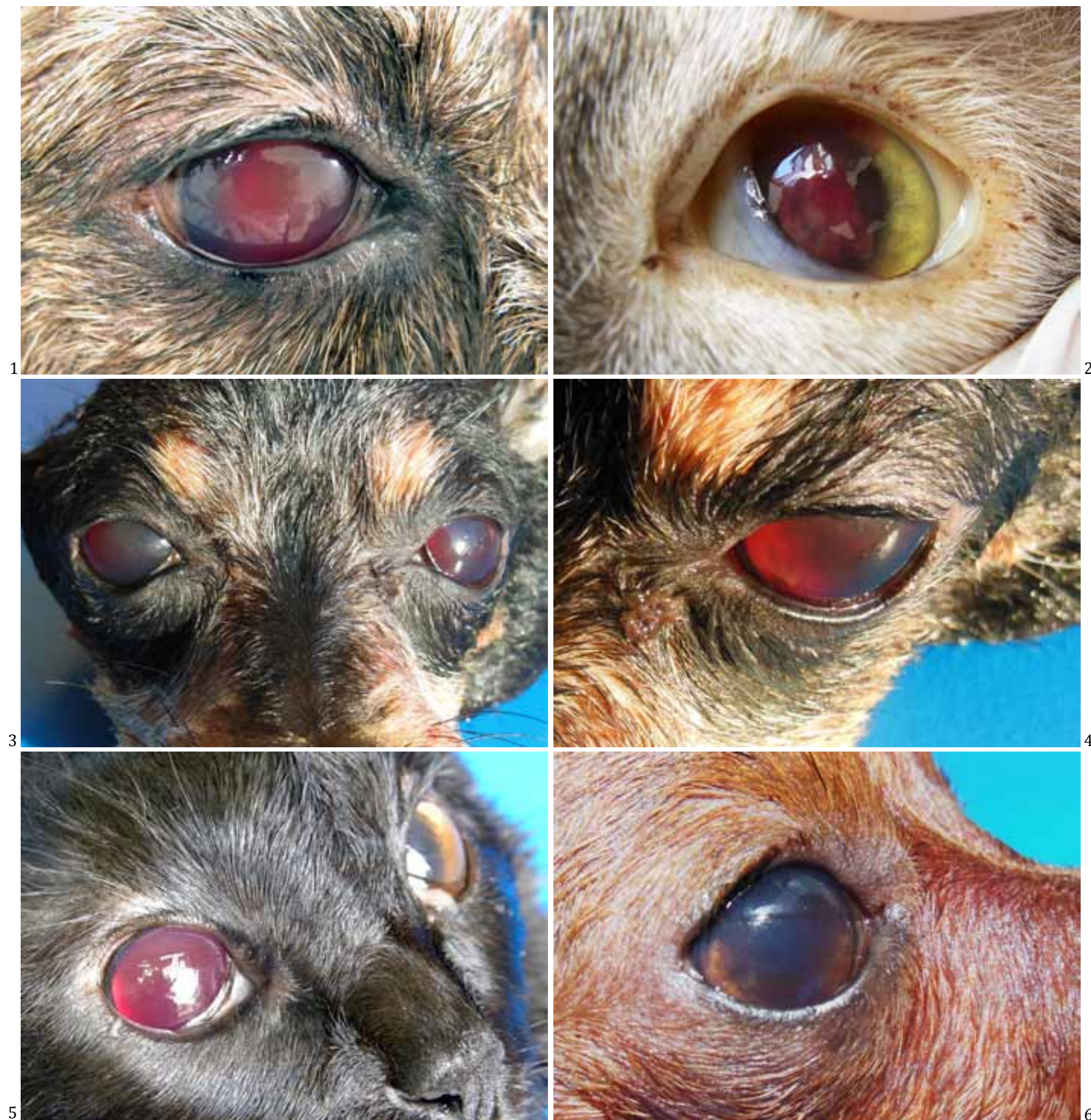

Fig.1. Dog \#10, unilateral hyphema, right eye (OD), ocular nature. The anterior chamber contains a large amount of blood due to a phacoclastic uveitis. Cataract also affected the left eye. This dog died due to septicemia.

Fig.3. Dog \#17, bilateral hyphema (OU), systemic nature. Both anterior chambers are completely filled with blood. Death occurred as a consequence of pyometra.

Fig.5. Cat \#2, unilateral hyphema, right eye (OD), systemic nature. In contrast with the hemorrhagic eye, one can notice the clearness of the contralateral eye. This cat suffered a septic peritonitis secondary to a perforated gastric ulcer.

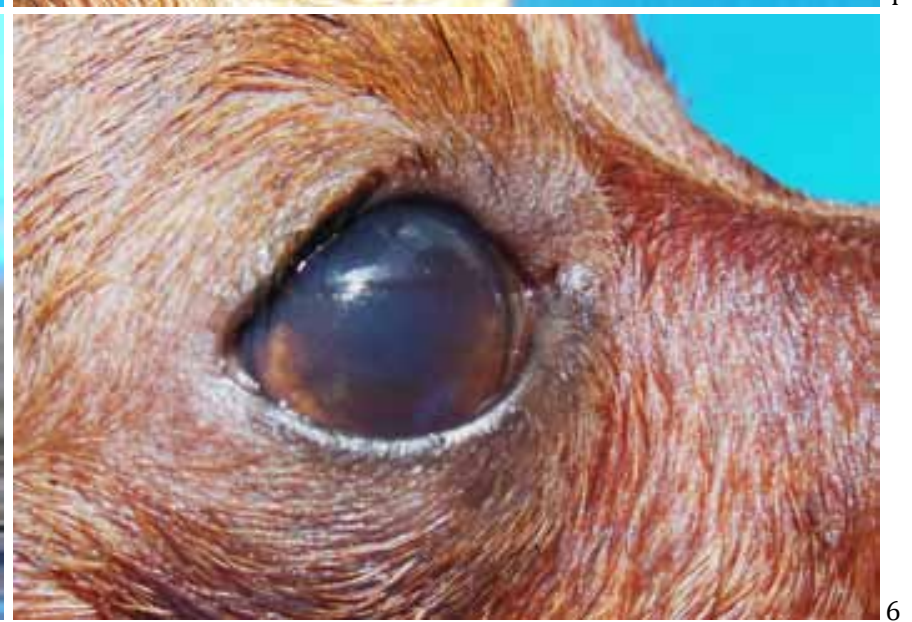

Fig.2. Cat \#3, unilateral hyphema, left eye (OS), systemic nature. There is a blood clot occupying half of the anterior chamber. Iris and pupil are easily seen here. Icterus can also be noted, and that explains why the color of the eyes changed from blue to green, as noticed by the owner. This cat was euthanized at an advanced stage of feline infectious peritonitis.

Fig.4. Dog \#17, bilateral hyphema (OU), systemic nature, same as Figure 3. Head was positioned towards the sun to highlight the red color. Blood is lightly translucent in this case.

Fig.6. Dog \#19, bilateral hyphema (OU), systemic nature. Instead of the traditional red color, in this dog a light brown blood is present in both eyes. Cause of death was steroid-responsive meningitis-arteritis syndrome. 
tasis in small caliber vessels in the vascular tunic of the eye, as well as in other organs.

In one dog, a unilateral hyphema was secondary to widespread melanoma. In this case, hyphema was attributed to vasculitis due secondary to intravascular, metastatic neoplastic cells. Neoplastic cells could be seen at few uveal vessels and lining the anterior chamber. Metastasis were present in many other organs.

Leucocytoclastic vasculitis as cause of uveitis was the reason for unilateral hyphema in one dog, as part of steroid-responsive meningitis-arteritis syndrome (Fig.6). In this dog, there were multiple foci of hemorrhage throughout the body, including meninges and anterior uvea. Microscopically, hemorrhage was secondary to vascular wall necrosis and infiltration by neutrophils.

Systemic hypertension was the most common underlying cause of hemorrhage in the anterior chamber in dogs, with five occurrences (Fig.7). Cardiac failure was the primary cause of systemic hypertension in three animals, all of which died due to distributive shock. One of these dogs also had bilateral mature cataract due to diabetes (Fig.8). A fourth dog, that use to be treated for epilepsy, died after an episode of seizure and pulmonary edema. Microscopic lesions in these four cases were subtle, and restricted to dilated vessels with mildly thickened walls in the uvea, choroid and retina. In all of them, hemorrhage was restricted to the anterior chamber. Lastly, one dog had bilateral hyphema due to systemic hypertension, but in this case, hemorrhage was due to retinal detachment. This dog was euthanized due to end-stage-kidney disease that culminated with nephrotic syndrome. There was bilateral retinal detachment and severe intraocular hemorrhage, both in the anterior and posterior chamber and vitreous body, as well as in the subretinal space (Fig.9). Retinal arterial vessels had ma-
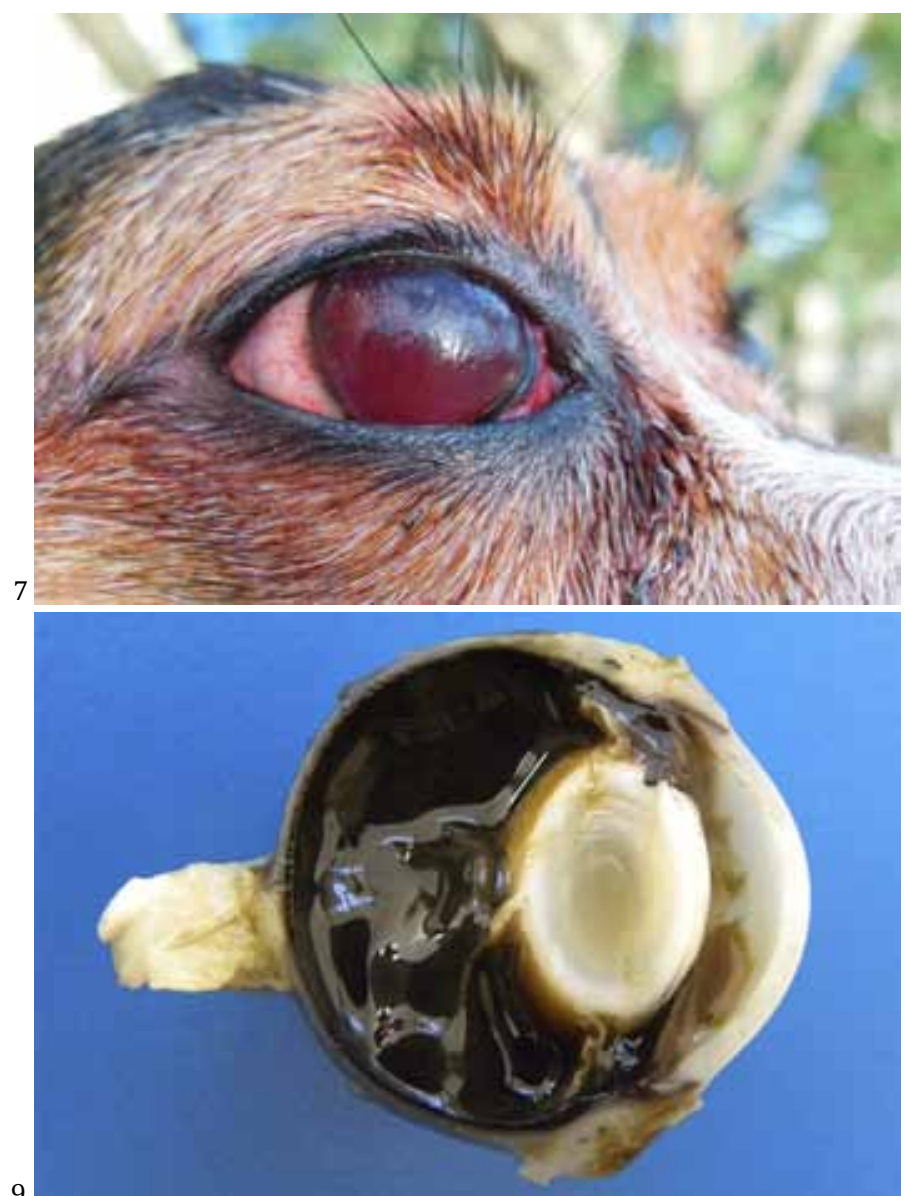

Fig.7. Dog \#14, unilateral hyphema, right eye (OD), systemic nature. The anterior chamber is diffusely red, effacing internal structures such as iris. Scleral vessels are lightly ingurgitated and third eyelid is hyperemic. This dog died due to cardiac failure.

Fig.9. Dog \#16, bilateral hyphema (OU), systemic nature. Vertical section of this globe shows diffuse retinal detachment and hemorrhage that occupies sub-retinal space, anterior and posterior chamber, and vitreous body. Contralateral eye was identical. This animal was euthanized due to nephrotic syndrome. Hyphema was caused by systemic hypertension secondary to renal failure.
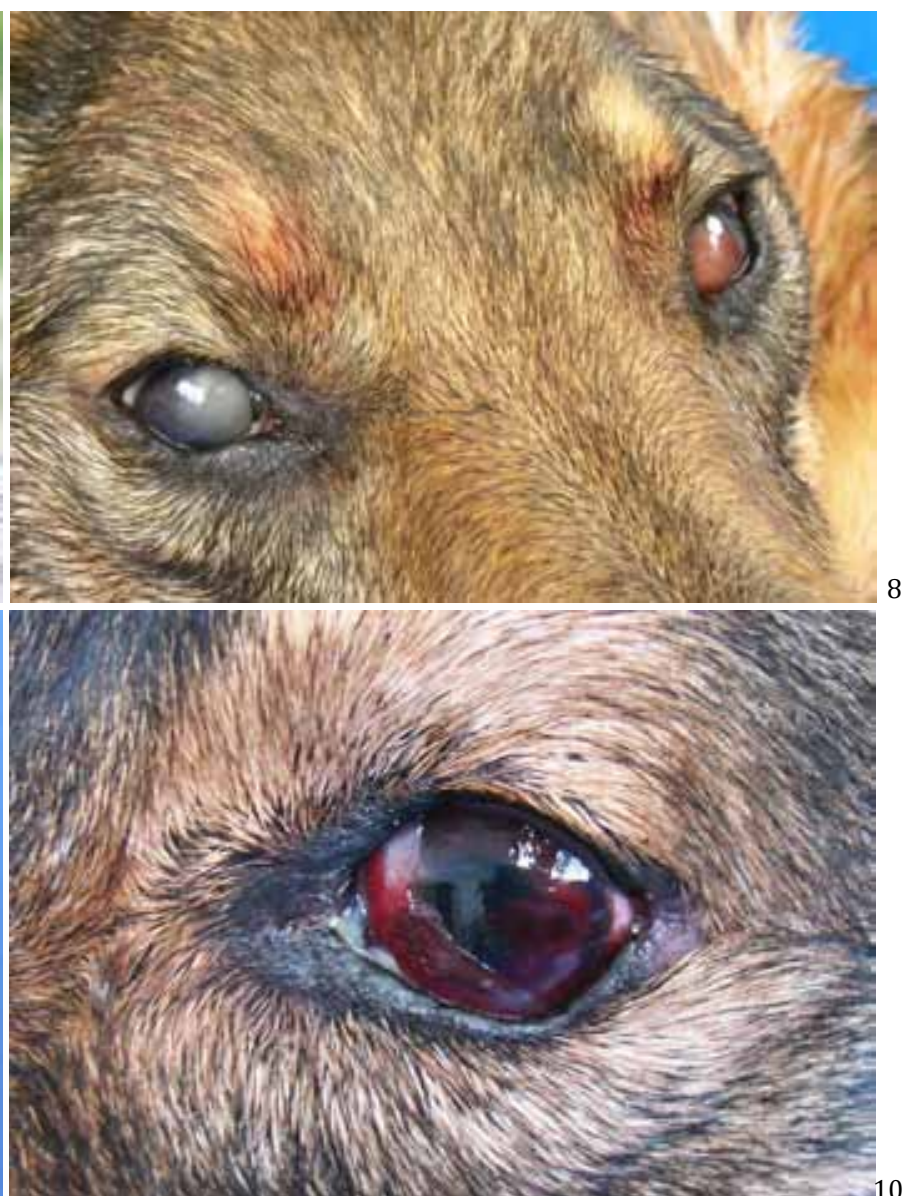

Fig.8. Dog \#13, unilateral hyphema, left eye (OS), systemic nature. There is a minimal collection of blood in the anterior chamber as a result of systemic hypertension. Bilateral cataract is also present. This dog died due to cardiac failure.

Fig.10. Dog \#20, unilateral hyphema, left eye (OS), systemic nature. In this case, hyphema is characterized by dark blood filling part of the anterior chamber. Blood did not clot during or after the necropsy. One can also notice the marked diffuse hyperemia in the third eyelid. Acquired coagulopathy presumably due to rodenticide poisoning lead this dog to death. 
Table 1. Canine and feline hyphema diagnosed during necropsy at LPV-UFSM ${ }^{\text {a }}(2000-2013)$

\begin{tabular}{|c|c|c|c|c|c|c|c|}
\hline \multirow[b]{2}{*}{$\#$} & \multicolumn{4}{|c|}{ Signalment } & \multicolumn{2}{|c|}{ Features of hyphema } & \multirow[t]{2}{*}{ Type/Cause of death } \\
\hline & Sp. ${ }^{b}$ & Sex & Breed & $\mathrm{Age}^{\mathrm{c}}$ & $\begin{array}{c}\text { Nature/ } \\
\text { Distribution }\end{array}$ & Mechanism & \\
\hline 1 & Cat & $\mathrm{F}^{\mathrm{d}}$ & Mixed & 3 & $\begin{array}{c}\text { Ocular/ } \\
\text { OS }^{\mathrm{e}}\end{array}$ & $\begin{array}{l}\text { Trauma, penetrating } \\
\text { (retinal detachment) }\end{array}$ & $\begin{array}{l}\mathrm{E}^{\mathrm{f}} / \text { Multiple } \\
\text { trauma }\end{array}$ \\
\hline 2 & Cat & $\mathrm{F}$ & Mixed & 11 & $\begin{array}{l}\text { Systemic/ } \\
\text { OD }^{\mathrm{g}}\end{array}$ & $\begin{array}{l}\text { Vasculitis, } \\
\text { septicemic }\end{array}$ & $\begin{array}{l}\mathrm{N}^{\mathrm{h}} / \text { Septicemia } \\
\text { (peritonitis) }\end{array}$ \\
\hline 3 & Cat & $\mathrm{M}^{\mathrm{i}}$ & Mixed & 1 & $\begin{array}{l}\text { Systemic/ } \\
\text { OS }\end{array}$ & $\begin{array}{l}\text { Vasculitis and uveitis, } \\
\text { pyogranulomatous }\end{array}$ & $\begin{array}{l}\text { E/FIPj } \\
\text { (dry form) }\end{array}$ \\
\hline 4 & Cat & M & Mixed & $<1$ & $\begin{array}{l}\text { Systemic/ } \\
\text { OU }^{\mathrm{k}}\end{array}$ & $\begin{array}{l}\text { Vasculitis and uveitis, } \\
\text { pyogranulomatous }\end{array}$ & $\begin{array}{l}\text { E/FIP } \\
\text { (dry form) }\end{array}$ \\
\hline 5 & Cat & M & Mixed & $<1$ & $\begin{array}{l}\text { Systemic/ } \\
\text { OU }\end{array}$ & $\begin{array}{l}\text { Vasculitis, uveitis } \\
\text { and chorioretinits, } \\
\text { pyogranulomatous }\end{array}$ & $\begin{array}{l}\text { E/FIP } \\
\text { (dry form) }\end{array}$ \\
\hline 6 & Cat & M & Mixed & $\mathrm{NA}^{1}$ & $\begin{array}{c}\text { Systemic/ } \\
\text { OU }\end{array}$ & $\begin{array}{l}\text { Coagulopathy, } \\
\text { acquired }\end{array}$ & $\begin{array}{l}\text { N/ Presumed roden- } \\
\text { ticide poisoning }\end{array}$ \\
\hline 7 & Dog & $\mathrm{F}$ & Pinscher & 3 & $\begin{array}{l}\text { Ocular/ } \\
\text { OD }\end{array}$ & $\begin{array}{l}\text { Trauma, blunt } \\
\text { (eye proptosis) }\end{array}$ & $\begin{array}{l}\text { N/Multiple } \\
\text { trauma }\end{array}$ \\
\hline 8 & Dog & M & NA & 4 & $\begin{array}{l}\text { Ocular/ } \\
\text { OD }\end{array}$ & $\begin{array}{l}\text { Trauma, } \\
\text { penetrating }\end{array}$ & $\begin{array}{l}\text { N/Multiple } \\
\text { trauma }\end{array}$ \\
\hline 9 & Dog & $\mathrm{F}$ & Mixed & 16 & $\begin{array}{l}\text { Ocular/ } \\
\text { OD }\end{array}$ & $\begin{array}{l}\text { Trauma, } \\
\text { penetrating }\end{array}$ & $\begin{array}{l}\mathrm{N} / \text { Septicemia } \\
\text { (intestinal necrosis) }\end{array}$ \\
\hline 10 & Dog & $\mathrm{F}$ & Mixed & 8 & $\begin{array}{l}\text { Ocular/ } \\
\text { OD }\end{array}$ & $\begin{array}{l}\text { Vasculitis, lens-induced } \\
\text { (phacoclastic uveitis) }\end{array}$ & $\begin{array}{l}\text { N/Septicemia } \\
\text { (mycotic gastritis)* }\end{array}$ \\
\hline 11 & Dog & M & Mixed & 15 & $\begin{array}{l}\text { Systemic/ } \\
\text { OD }\end{array}$ & $\begin{array}{l}\text { Vasculitis, } \\
\text { neoplastic }\end{array}$ & $\begin{array}{l}\text { N/Widespread } \\
\text { melanoma* }\end{array}$ \\
\hline 12 & Dog & $\mathrm{CF}^{\mathrm{m}}$ & Pinscher & 10 & $\begin{array}{l}\text { Systemic/ } \\
\text { OD }\end{array}$ & $\begin{array}{l}\text { Systemic } \\
\text { hypertension }\end{array}$ & $\begin{array}{l}\text { N/Cardiac failure } \\
\text { (endocardiosis) }\end{array}$ \\
\hline 13 & Dog & $\mathrm{F}$ & Mixed & 11 & $\begin{array}{l}\text { Systemic / } \\
\text { OS }\end{array}$ & $\begin{array}{l}\text { Systemic } \\
\text { hypertension }\end{array}$ & $\begin{array}{l}\mathrm{N} / \text { Cardiac } \\
\text { failure }\left(\mathrm{HCM}^{\mathrm{n}}\right)^{*}\end{array}$ \\
\hline 14 & Dog & M & Mixed & 10 & $\begin{array}{l}\text { Systemic/ } \\
\text { OD }\end{array}$ & $\begin{array}{l}\text { Systemic } \\
\text { hypertension }\end{array}$ & $\begin{array}{l}\mathrm{N} / \text { Cardiac } \\
\text { failure }\left(\mathrm{DCM}^{\circ}\right)\end{array}$ \\
\hline 15 & Dog & M I & Dachshund & 8 & $\begin{array}{l}\text { Systemic/ } \\
\text { OS }\end{array}$ & $\begin{array}{l}\text { Systemic } \\
\text { hypertension }\end{array}$ & $\begin{array}{l}\text { N/Idiopathic } \\
\text { epilepsy }\end{array}$ \\
\hline 16 & Dog & M D & Dobermann & 7 & $\begin{array}{l}\text { Systemic/ } \\
\text { OU }\end{array}$ & $\begin{array}{l}\text { Systemic hypertension } \\
\text { (retinal detachment) }\end{array}$ & $\begin{array}{l}\text { E/Renal } \\
\text { failure }\left(N^{p}\right)\end{array}$ \\
\hline 17 & Dog & $\mathrm{F}$ & Pinscher & 9 & $\begin{array}{l}\text { Systemic/ } \\
\text { OU }\end{array}$ & $\begin{array}{l}\text { Vasculitis, } \\
\text { septicemic }\end{array}$ & $\begin{array}{l}\text { N/Septicemia } \\
\text { (pyometra) }\end{array}$ \\
\hline 18 & Dog & $\mathrm{F}$ & Pinscher & 1 & $\begin{array}{l}\text { Systemic/ } \\
\text { OU }\end{array}$ & $\begin{array}{l}\text { Vasculitis, } \\
\text { septicemic }\end{array}$ & $\begin{array}{l}\text { N/Septicemia } \\
\text { (pyometra) }\end{array}$ \\
\hline 19 & Dog & F & Pinscher & 11 & $\begin{array}{l}\text { Systemic/ } \\
\text { OS }\end{array}$ & $\begin{array}{l}\text { Vasculitis } \\
\text { (leucocytoclastic) }\end{array}$ & $\begin{array}{l}\text { N/ } \\
\text { SRMA }^{q}\end{array}$ \\
\hline 20 & Dog & $\mathrm{CM}^{\mathrm{r}}$ & Mixed & 6 & $\begin{array}{l}\text { Systemic/ } \\
\text { OD }\end{array}$ & $\begin{array}{l}\text { Coagulopathy, } \\
\text { acquired }\end{array}$ & $\begin{array}{l}\text { N/ Presumed roden- } \\
\text { ticide poisoning }\end{array}$ \\
\hline
\end{tabular}

${ }^{\mathrm{a}}$ Laboratório de Patologia Veterinária da Universidade Federal de Santa Maria, ${ }^{\mathrm{b}}$ species, ${ }^{\mathrm{c}}$ in years, ${ }^{\mathrm{d}}$ female, ${ }^{\mathrm{e}}$ left eye (oculus sinister), ${ }^{\mathrm{f}}$ euthanasia, ${ }^{\mathrm{g}}$ right eye (oculus dexter), ${ }^{\mathrm{h}}$ natural, ${ }^{\mathrm{i}}$ male, ${ }^{\mathrm{i}}$ feline infectious peritonitis, ${ }^{\mathrm{k}}$ both eyes (oculus uterque), ${ }^{1}$ not available, ${ }^{\mathrm{m}}$ castrated female, ${ }^{\mathrm{n}}$ hypertrophic cardiomyopathy, ${ }^{\circ}$ dilated cardiomyopathy, ${ }^{\mathrm{p}}$ nephrotic syndrome, ${ }^{\mathrm{q}}$ steroid-responsive meningitis-arteritis, ${ }^{\mathrm{r}}$ castrated male, ${ }^{*}$ bilateral cataract.

rkedly thickened walls. This was the most severe case of hyphema in this study.

Two animals, a dog and a cat, presented hyphema due to acquired coagulopathy presumably caused by rodenticide poisoning (Fig.10). Toxicological analysis was not performed in any of these cases. The presumptive diagnosis was based in the clinical history, gross findings of large amounts of dark granules (which resembled a commercial presentation of rodenticide) amidst the gastric contents, multifocal hemorrhages, and non-clotted blood, including the blood within the eye. In both cases, there were foci of hemorrhage in multiple internal organs, and blood did not clot during necropsy. Microscopically, multifocal areas of acute, moderate hemorrhage were observed in the anterior and posterior uvea and retina, without other signs of vascular damage.

Data on signalment, characteristics of hyphema, and cause of death or reason for euthanasia of each case are present at Table 1.

\section{DISCUSSION}

Hyphema was considered secondary to systemic disease in a large proportion of cases in this study (75\%) when compared to primary ocular disease (25\%). Vasculitis from various causes and systemic hypertension were the most common underlying causes for the development of hyphema, $45 \%$ and $25 \%$, respectively, followed by trauma, either blunt or penetrating (20\%), and acquired coagulopathy 
(10\%). Concurrent involvement of more than one mechanism is common in hyphema formation (Komáromy et al. 1999), and we believe that this happened at least in three situations in this study. Discussion starts with hyphema caused by primary ocular lesions.

According to internal medicine literature, blunt or sharp trauma to the globe is the most frequent cause for hyphema in small animals (Powell 2002), while here it was the third in decreasing order. This difference might relate to the way hyphema was approached in this study, where ocular hemorrhage was evaluated during necropsy. Perhaps traumatic hyphema is less complicated than other types of hyphema in everyday practice and simply does not reach the necropsy floor as frequently as other systemic, life-threating diseases that manifest intraocular hemorrhage, as most hyphemas are small and resorbed spontaneously in a few days (Miller 2008).

Whereas blunt trauma to the head seldom results in hyphema because the eyeball is protected by anterior portions of the bony orbit and orbital soft tissues, severe blunt trauma to the anterior orbital rim or periorbital soft tissues and eyeball may cause hemorrhage in the anterior chamber (Komáromy et al. 1999) due to retinal detachment or tear of the ciliary body (Book et al. 2008). The dog that suffered blunt trauma presented hyphema after being hit by a car and suffering ocular proptosis. Penetrating trauma with corneal laceration and traumatic uveitis were due to car accident (two cases) and a presumed animal fight (one case).

Cataract was considered the primary underlying cause of hyphema in one dog. It is believed, however, that there was concurrent involvement of, at least, one mechanism in this case. This dog presented bilateral cataract with unilateral phacoclastic uveitis and profuse intraocular hemorrhage, especially in anterior chamber. Because hyphema is a frequent manifestation of traumatic uveitis, but is rarely seen with phacolytic uveitis (Grahn 2002), we believe that the hemorrhage was influenced by an ongoing septicemic condition due to zygomycotic gastritis. There were no evidence of hyphae within the hyphemic eye, but a marked vascular invasion was observed in the gastric wall. Mild protein exudation was observed in the contralateral eye.

Vascular endothelial cell abnormalities may result in transmural extravasation of blood from vascular channels in the iris and ciliary body, resulting in breakdown of the blood-aqueous barrier and hyphema. Vasculitis may result from primary or secondary immune-mediated destruction of endothelial cells (e.g., immune-mediated vasculitis, toxoplasmosis), infectious diseases (e.g., leptospirosis, Rocky Mountain spotted fever, feline infectious peritonitis), neoplasia, or systemic inflammatory response syndrome (e.g., sepsis) (Komáromy et al. 1999).

Half of feline cases of hyphema happened as part of feline infectious peritonitis (FIP). Hemorrhage was bilateral in two cats and unilateral in one. Ocular involvement is very common in "dry" form of FIP (Aroch et al. 2008) and less common in the purely effusive form of the disease (Dubielzig 2010). Because the nature of the disease is vasculitis, hemorrhage into the anterior chamber, retinal hemorrhages and detachment may develop (Stiles 2006, Aroch et al.
2008), although the classic necrotizing vasculitis is seen only rarely (Njaa \& Wilcock 2012). Additional to the damaged vascular walls as source of bleeding, bilateral PIFM were present in at least one cat.

Three animals presented hyphema due to septicemic vasculitis, two dogs and one cat. Both dogs died due to pyometra, while the cat died after a perforated gastric ulcer lead to a severe peritonitis. In all cases, small caliber vessels with thrombi and neutrophilic leukocytostasis could be seen diffusely, including in the ocular vessels. In the eyes, there was anterior and posterior mild neutrophilic uveitis and choroiditis and intravascular microthrombi. Ocular reflexes of septicemia are more commonly reported in large animals, especially horses and cattle (Aroch et al. 2008), but may happen in small animals due to, for instance, pyometra (Komáromy et al. 1999). A second mechanism might have played a role in these cases. In overwhelming septicemia, thrombocytopenia can occur from the excessive consumption of platelets, which can lead to disseminated intravascular coagulation (Aroch et al. 2008), and hyphema (Komáromy et al. 1999).

Hyphema was secondary to metastatic neoplasia in one dog. In this case, bleeding was attributed to intravascular neoplastic thrombi, and its nature was classified as vasculitis (Komáromy et al. 1999). Spontaneous unilateral hyphema has long been cited as a clue to the presence of intraocular neoplasia, even though the explanation was obscure. It now seems that the bleeding originates from the fragile vessels of a PIFM, which is no more than a proliferation of granulation tissue from the stroma of the iris (or retina) formed as an "accidental" response to the diffusion of growth factors produced by the tumor itself (Wilcock 2008). However, no PIFM was observed in this dog. Besides the widespread neoplasm, this dog had bilateral cortical cataract.

Vasculitis due to steroid-responsive meningitis-arteritis (SRMA) was implicated as cause of hyphema in one dog. The authors could not find a report of hyphema due SRMA, but the histologic ocular lesions seem to justify such diagnosis. The dog presented leucocytoclastic, neutrophilic vasculitis with thrombi and hemorrhage in the brain and ocular vessels. The characteristic lesion of SRMA is fibrinoid arteritis and leptomeningeal inflammation consisting of predominantly neutrophils and scattered lymphocytes, plasma cells and macrophages and associated necrotizing fibrinoid arteritis. Acute thrombosis of the vasculature may create ischemic changes in the nervous parenchyma, and in chronic lesions re-canalization of thrombi may occur (Summers et al. 1995).

Hyphema attributable to systemic hypertension is most common in old cats and dogs, and is usually caused by cardiac (Miller 2008) or renal insufficiency (Komáromy et al. 1999). Chronic high arterial pressure results in arteriosclerosis and autoregulatory arteriolar vasospasm. Arteriolar disease causes ischemia and capillary permeability changes and eventually hemorrhage. Intraocular hemorrhage may therefore occur as a direct result of vascular damage (Dubielzig 2010). However, most cases of hyphema from vascular hypertension are attributable to retinal detachment and hemorrhage, most likely in response to choroidal vascular 
hypertension (Komáromy et al. 1999). Retinal detachment can also lead to pre-iridal fibrovascular proliferation, another possible source of bleeding in the anterior chamber (Dubielzig 2010). Hyphema may be less commonly caused by tearing of retinal vasculature that occurs during retinal detachment (Komáromy et al. 1999). In this study, systemic hypertension was observed in five dogs, with seven to eleven years of age. Cardiac failure was the most common cause, with three occurrences, while renal failure was observed in a dog that was euthanized because of a severe nephrotic syndrome. This dog was the only to present retinal detachment. In the other dogs, hemorrhage was presumed to occur secondarily to vascular damage. A dog that died due to a dilated cardiomyopathy also had diabetes mellitus and bilateral cataract. As cardiac failure, diabetes can cause systemic arterial hypertension, and the primary cause for vascular damage was not clear in this case because both diseases were in advanced stage of development.

Presumed rodenticide poisoning was the cause of widespread hemorrhages, including unilateral hyphema, in two animals, a dog and a cat. Lesions included multifocal hemorrhages throughout the body and non-clotting blood, including the blood within the eye. Interestingly, it is considered valuable to establish whether the blood is clotted or not. Clotted blood in the anterior chamber is often seen when the cause is anterior uveitis or trauma, whereas hemorrhage caused by coagulation disorders is unclotted (Townsend et al. 2009). Hyphema has been documented with anticoagulant rodenticide exposure (Trbolova 2009), but it is rarely mentioned in texts that discuss clinical signs of this toxicity. This may be because ocular lesions are uncommon relative to other signs, or because they are usually mild in comparison to the more life-threatening hemorrhage that typically occurs (Kuhn \& Hendrix 2013).

\section{CONCLUSIONS}

In twenty cases of hyphema diagnosed post-mortem in dogs and cats, hyphema secondary to or occurring as part of systemic diseases was three times more common than hyphema due to primary ocular diseases.

All cases of hyphema primary to the eye were unilateral, and bilateral hyphema was always part of systemic diseases.

Feline infectious peritonitis (FIP) was the main cause of hyphema in cats, while septicemia and systemic hypertension were the most common entities associated to hemorrhage in the anterior chamber in dogs.

Acknowledgements.- CNPq sponsored a 12-month sandwich scholarship for the first author at the Department of Veterinary Pathology of the Iowa State University (ISU) under supervision of Dr. Joseph S. Haynes. Both ins- titutions, CNPq and ISU, their staff and faculty, should be gratefully acknowledged.

\section{REFERENCES}

Aroch I., Ofri R. \& Sutton G.A. 2008. Ocular manifestations of systemic diseases, p.374-418. In: Maggs D.J., Miller P.E. \& Ofri R. (Eds), Slatter's Fundamentals of Veterinary Ophthalmology. $4^{\text {th }}$ ed. Saunders Elsevier, St Louis.

Bjerkås E., Ekesten B., Narfström K. \& Grahn B. 2009. Visual impairment, p.116-202. In: Peiffer R.L. \& Petersen-Jones S.M. (Eds), Small Animal Ophthalmology: a problem-oriented approach. 4th ed. Saunders, Philadelphia.

Book B.P., Van der Woerdt A. \& Wilkie D.A. 2008. Ultrasonographic abnormalities in eyes with traumatic hyphema obscuring intraocular structures: 33 cases (1991-2002). J. Vet. Emerg. Crit. Care 18:383-387.

Dubielzig R.R., Ketring K.L., McLellan G.J. \& Albert D.M. 2010. Non-surgical trauma, p.81-114. In: Ibid. (Eds), Veterinary Ocular Pathology: a comparative review. Elsevier, Edinburgh.

Grahn B.H. 2002. Phacolytic uveitis, p.205-207. In: Riis R.C. (Ed.), Small Animal Ophthalmology Secrets. Hanley and Belfus, Philadelphia.

Komáromy A.M., Ramsey D.T., Brooks D.E., Ramsey C.C., Kallberg M.E. \& Andrew S.E. 1999. Hyphema. I. Pathophysiologic considerations. Compend. Contin. Educ. Vet. 21:1064-1069.

Kuhn S.E. \& Hendrix D.V.H. 2013. Unilateral subconjunctival and retrobulbar hemorrhage secondary to brodifacoum toxicity in a dog. Case Reports in Veterinary Medicine:1-6.

Miller P.E. 2008. Ocular emergencies, p.419-426. In: Maggs D.J., Miller P.E. \& Ofri R. (Eds), Slatter's Fundamentals of Veterinary Ophthalmology. $4^{\text {th }}$ ed. Saunders Elsevier, St Louis.

Moreland R.E. 2009. The necropsy procedure, p.21-67. In: Ibid. (Ed.), Color Atlas of Small Animal Necropsy. Remsoft Publishing, London.

Njaa B.L. \& Wilcock B.P. 2012. The ear and eye, p.1153-1244. In: Zachary J. \& McGavin D. (Eds), Pathologic Basis of Veterinary Disease. $5^{\text {th }}$ ed. Elsevier Mosby, St Louis.

Powell C.C. 2002. Ocular hemorrhage, p.214-221. In: Riis R.C. (Ed.), Small Animal Ophthalmology Secrets. Hanley \& Belfus, Philadelphia.

Sorrell M.S., Taylor K.H. \& Fish R.E. 2008. Secondary acute anterior uveitis with hyphema in a purpose-bred kitten. J. Am. Assoc. Lab. Anim. Sci. 47:57-60.

Stiles J. 2006. Ocular infections, 974-990. In: Greene C.E. (Ed.), Infectious Diseases of the Dog and Cat. $3^{\text {rd }}$ ed. W.B. Saunders, St Louis.

Summers B.A., Cummings J.F. \& de Lahunta A. 1995. Inflammatory diseases of the central nervous system, p.114-116. In: Ibid. (Eds), Veterinary Neuropathology. Mosby, St Louis.

Townsend W., Bedford P. \& Jones G. 2009. Abnormal appearance, p.67-115. In: Peiffer R.L. \& Petersen-Jones S.M. (Eds), Small Animal Ophthalmology: a problem-oriented approach. $4^{\text {th }}$ ed. W.B. Saunders, Philadelphia.

Trbolova A. 2009. Hyphema in dogs: 91 cases. Vet. Ophthalmol. 12:61-70.

Wilcock B.P. 2008. General pathology of the eye, p.62-80. In: Maggs D., Miller P. \& Ofri R. (Eds), Slatter's Fundamentals of Veterinary Ophthalmology. $4^{\text {th }}$ ed. Saunders Elsevier, St Louis.

Willis AM. 2003. Diseases of the anterior uveal tract, p.978-987. In: Morgan R.V., Bright R.M. \& Swartout M.S. (Eds), Handbook of Small Animal Practice. $4^{\text {th }}$ ed. W.B. Saunders, Philadelphia. 